\title{
Makna Subscriber Bagi Youtuber Kota Bandung
}

\author{
Achwan Noorlistyo Adi, Jenny Ratna Suminar, Nuryah Asri Sjafirah \\ Universitas Padjadjaran \\ Email : noorlistyo13@gmail.com \\ J1. Raya Bandung-Sumedang KM. 21, Jatinangor, Kab. Sumedang 45363 \\ Telp. (022) 84288888 Faks. (022) 84288898 Surel: humas@unpad.ac.id
}

Submitted: 10 October 2019 Revised: 11 October 2019 Accepted: 14 October 2019

\begin{abstract}
ABSTRAK
Membuat suatu video online adalah salah satu penyalur ide kreativitas yang tentunya dimiliki oleh seorang video maker, termasukYouTuber. Seorang YouTuber akan menganggap dirinya diapresiasi jika ada orang lain yang menonton video mereka. Apalagi jika penonton tersebut kemudian menjadi penonton setia ataupun pelanggan dari YouTube Channel dari seorang YouTuber tersebut. Untuk mendapatkan jumlah subscriber yang banyak, tentu perlu kerja keras dalam membuat konten yang kreatif, menarik penonton, dan berkualitas. Ketiga hal tersebut berjalan dengan proses yang tidak mudah. Banyak di luar sana yang beranggapan untuk menjadi YouTuber cukup dengan sekedar mengunggah video ke YouTube tanpa mementingkan estetika, konsep, serta proses kreatif dari video tersebut. Subscriber pun menjadi tolok ukur kesuksesan para YouTuber, begitu pun YouTuber di Kota Bandung. YouTube sendiri memberikan beberapa penghargaan bagi para YouTuber yang mampu mencapai jumlah subscriber tertentu. Melihat fenomena tersebut, tujuan dilakukannya penelitian ini yaitu untuk mengetahui makna subscriber bagi YouTuber Kota Bandung. Penelitian ini menggunakan paradigm konstruktivis dengan pendekatan kualitatif, metode fenomenologi serta teori interaksi simbolik. Pengumpulan data diambil dengan wawancara mendalam kepada 3 orang YouTuber Kota Bandung yaitu Kery Astina, Minyo, dan Eno Bening. Makna subscriber bagi YouTuber Kota Bandung adalah sebagai supporter, sebagai teman, sebagai penentu indicator rate card, dan sebagai pihak yang selalu memberikan feedback kepada para YouTuber.
\end{abstract}

Kata Kunci: kreator konten, makna subscriber, teori interaksi simbolik, youtuber

\begin{abstract}
Making an online video is one of the channelling ideas of creativity which is certainly owned by a video maker, including a YouTuber. A YouTuber will consider himself appreciated if someone else watches their video. Especially if the audience then becomes a loyal audience or subscriber of the YouTube Channel of the YouTuber. To get a large number of subscribers, of course, you need to work hard in creating creative contents, attract viewers, and have quality. These three things run with an uneasy process. Many out there think that becoming a YouTuber is enough to simply upload a video to YouTube without regarding to the aesthetics, concepts and creative processes of the video. Subscriber is also a benchmark for the success of YouTubers, as well as YouTubers in Bandung. YouTube itself gives several awards for YouTubers who can reach a certain number of subscribers. Seeing this phenomenon, the purpose of this research is to find out the meaning of subscribers for YouTubers in Bandung. This research uses a constructivist paradigm with qualitative approach, phenomenological methods and symbolic interaction theory. Data collection was taken by in-depth interviews with 4 Bandung YouTubers namely Kery Astina, Minyo, Eno Bening and Hisqie Furqoni. The meaning of the subscribers for the Bandung YouTubers is as a supporter, as a friend, as a determinant of the rate card indicator, and as a party that always gives feedback to YouTubers.
\end{abstract}

Keywords: content creator, means of subscriber, simbolic interaction theroy, youtuber 


\section{PENDAHULUAN}

Pergerakan peradaban yang semakin hari semakin maju, mampu menghadirkan kecanggihan di berbagai sektor. Salah satunya adalah kecanggihan dalam sekor teknologi informasi dan komunikasi. Munculnya platform multimedia saat ini mendorong kita sebagai manusia yang selalu mengikuti perubahan jaman untuk melakukan berbagai hal terkait dengan kebutuhan informasi dan komunikasi tanpa ada lagi batas ruang dan waktu.

Perubahan besar yang dapat dilihat kasat mata adalah hampir semua orang di dunia ini dapat saling berkomunikasi dengan cepat dan mudah hanya dengan memanfaatkan media baru yang dinamakan internet. Inovasi dalam media internet yang dihadirkan oleh salah satu penyedia layanan besar di dunia internet, Google, mampu memberikan sebuah kemudahan untuk kebutuhan mengunggah berbagai video yang diproduksi oleh para penggunanya. Layanan tersebut lebih populer disebut dengan YouTube(Hajar, 2018).

YouTube adalah sebuah situs yang memiliki fitur untuk berbagi video. Media baru bergenre multimedia ini juga termasuk ke dalam salah satu media sosial karena memungkinkan terjadinya interaksi antar pengguna saat mereka memiliki saluran YouTube untuk mengunggah, menonton, dan berbagi video. Kebanyakan konten di YouTube diunggah secara perorangan. Meskipun tidak sedikit pula perusahan-perusahan media yang sudah memiliki frekuensi analog ataupun digital lainya yang turut mengunggah konten material video mereka ke YouTube (Adi, 2017).
Berdiri sejak 23 April 2005 silam, YouTube mengatakan bahwa video yang diunggah ada sekitar 60 jam setiap menitnya. Tiga perempat diantaranya berasal dari luar Amerika Serikat. Dari data 2008, pengunjung YouTube menghabiskan rata-rata 15 menit sehari untuk menonton video di kanal yang tersedia di platform mereka (Searbrook, 2012).

Jumlah jam yang diluangkan orang- orang untuk menonton video (alias waktu tonton) di YouTube naik $60 \%$ per tahunnya, dan merupakan pertumbuhan terpesat yang pernah dilihat dalam kurun waktu 2 tahun terakhir. Jumlah orang yang menonton YouTube per hari naik sebesar $40 \%$ per tahun(Faiqah, Nadjib, \& Amir, 2016).

Durasi menonton video YouTube di Indonesia bertambah $130 \%$ di kuartal III 2014 ke kuartal IV 2015. Begitu pula jumlah konten yang diupload bertambah 600\%. Pengunjung YouTube di Indonesia tidak hanya datang dari kalangan remaja, tetapi juga banyak dari kalangan anakanak hingga orang tua (Goenawan, 2015).

Sebagai media sosial dengan genreplatform multimedia, perkembangan YouTubeini terlihat sangat pesat dari tahun ke tahun, terutama fenomena content creator-nya. Berbeda dengan media sosial lainnya, YouTube lebih berfokus pada konten berbagi video dengan durasi yang sangat panjang. Trend ini pun berkembang di Indonesia. We Are Social menyebutkan bahwa pada Januari 2018, YouTube merupakan media sosial yang menduduki peringkat pertama di Indonesia dengan persentase 43\%(Riyanto, 2019).

Bahkan data terbaru dari We Are Social pada Januari 2019 menyebutkan 
bahwa YouTube masih memuncaki trend media sosial yang sering digunakan di Indonesia. YouTube mendapatkan peringkat pertama dengan persentase sebesar $88 \%$. Di posisi kedua diperoleh WhatsApp dengan persentase $83 \%$. Ketiga ditempati oleh Facebook dengan persentase $81 \%$ (Social, 2019)

Karakteristik dari media YouTube antara lain, tidak ada batasan durasi untuk mengunggah video, sistem pengamanan yang mulai akurat, berbayar (setiap YouTuber yang sudah mempunyai 1.000 subscriber dan telah ditonton sebanyak 4.000 jam akan mendapatkan honorarium oleh YouTube), sistem offline (dapat menonton tayangan video tanpa harus menggunakan internet, tetapi sebelumnya harus diunduh terlebih dahulu), dan terakhir adalah terdapat fitur editor sederhana sesaat setelah mengunggah video (Faiqah, Nadjib, \& Amir, 2016).

Meningkatnya konten YouTube di Indonesia beberapa tahun terakhir ini tidak lepas dari peran penting para YouTuber itu sendiri. Mereka melihat bahwa kebutuhan hiburan di Indonesia sangat besar, terutama di era digital seperti saat ini. Dengan melihat kesempatan tersebut, para YouTuber mencoba mengeksplorasi ide kreatifnya agar menjadi karya yang bermanfaat bagi orang banyak terutama para subscriber mereka, dengan tujuan lainnya untuk mendapatkan rasa kagum dari para subscriber-nya. Seseorang yang mengekspresikan diri mereka melalui media sosial untuk membuat pengguna lainnya kagum atas dirinya (Crystal, 2011).

YouTuber adalah orang yang menjadi content creator, mereka memiliki berbagai ide kreatif yang dituangkan dalam sebuah karya video yang kemudian mereka unggah ke YouTube. Setiap YouTuber ini pun tentu memiliki pandangan dan segmentasi yang berbedabeda. Tidak serta merta mereka membuat sebuah video tanpa melihat siapa penonton mereka dan juga konten seperti apa yang disukai oleh para penontonnya. Pemikiran peneliti ini sejalan dengan apa yang dituliskan oleh Brad and Debora.

"YouTuber adalah seseorang atau sekelompok orang yangmembuat akun di YouTube yang kemudian mengubah jenis akun tersebut menjadi saluran YouTube dengan memilih berbagai kategori yang mencerminkan tujuannya membuat video seperti kategori komedian, reporter, musisi, dan lain sebagainya." (Brad \& Debora, 2009).

Keterbukaan masyaraka di era jejaring ini membuat YouTube tidak hanya memberikan ruang bagi para kreator untuk hanya mengekspresikan diri mereka sendiri, melainkan pula memberikan ruang baru bagi para penonton YouTube untuk menentukan channel mana yang ingin mereka tonton sebagai sarana pemenuhan kebutuhan akan hiburan, informasi dan lain sebagainya. Bertemunya kedua kepentingan tersebut menjadi dasar dari munculnya engagement antara para YouTuber dan juga para subscriber(Labas \& Yasmine, 2017).

Guna menjaga tren positif tersebut, Google memiliki beberapa rencana positif ke depannya untuk terus mengembangkan layanan mereka. Ada tiga fokus utama mereka saat ini, yatu pengembangan kreator (YouTuber) di Indonesia, mempererat hubungan dengan komunitas YouTube di Indonesia, serta memudahkan akses YouTube bagi pengguna internet yang ada di Indonesia. Saat ini langkah positif dan nyata yang dilakukan oleh 
Google yaitu mereka menyediakan sebuah tempat khusus yang diberi nama YouTube Space Jakarta untuk para kreator lokal. Ruang kreatif sementara dari YouTube ini berlokasi di Rumah Maroko, Jalan Tasikmalaya No4. Menteng, Jakarta Pusat (Fikrie, 2017)

Istilah lain yang biasa muncul di media YouTube adalah subscriber.Subscriber adalah mereka yang menjadi penonton setia dan senantiasa menantikan video terbaru di channel para YouTuber yang ia pilih. Subscriber sangat berperan dalam kesuksesan para YouTuber di YouTube, karena mereka cenderung lebih sering menonton channel para YouTuber tersebut dibandingkan penonton yang tidak subscribe. Jika mereka mengaktifkan lonceng notifikasi, mereka akan diberi tahu ketika para YouTuber tersebut mengumumkan adanya video baru (Academy, 2018).

Subscriber dalam suatu channelpun menentukan penghargaan yang diberikan oleh YouTube kepada para YouTuber itu sendiri. Setiap capaian tertentu, YouTube akan memberikan penghargaan berupa YouTube Play Button. Jika jumlah subscriber-nya sudah mencapai 100.000 subscriber, YouTube akan memberikan Silver Play Button kepada para YouTubernya. Kemudian, apabila YouTuber tersebut mencapai 1.000.000 subscriber, YouTube akan memberikan Gold Play Button, dan apabila YouTuber tersebut mencapai 10.000.000 subscriber, YouTube akan memberikan Diamond Play Button (YouTube, 2018)

Di Kota Bandung sendiri, terdapat YouTuber yang memiliki subscriber lebih dari 100.000. Di antaranya adalah Kery Astina, Eno Bening, dan Minyo. Kery Astina kini telah memiliki 2,1 Juta
subscriber(YouTube, 2019), Eno Bending kini telah memiliki 419.000 subscriber(YouTube, 2019), dan Minyo memiliki 133.000 subscriber(YouTube, 2019).

Pemilihan YouTuber Kota Bandung bukan tanpa alasan. YouTuber Kota Bandung menaruh 2 kursiuntuk posisi YouTube Ambassador Indonesia.Kedua YouTuber tersebut adalah Minyo dan Eno Bening.Sedangkan Kery Astina adalah satu-satunya YouTuber Kota Bandung yang berhasil menjadi peserta YouTube Next Up 2017.Dengan melihat fenomena YouTuber dan subscriber ini, peneliti melakukan penelitian yang berfokus pada "Makna Subscriber Bagi YouTuber Kota Bandung."

\section{METODE PENELITIAN}

Penelitian ini menggunakan paradigma konstruktivis yang berusaha untuk melihat bahwa realita sosial dibangun oleh pemaknaan dari masyarakat yang ada di dalamnya.Pendekatan penelitian yang digunakan adalah metode kualitatif. Jane Richie mengungkapkan bahwa penelitian kualitatif adalah upaya untuk menyajikan dunia sosial dan perspektifnya di dalam dunia dari segi konsep, perilaku, persepsi, dan persoalan tentang manusia yang diteliti. (Moleong, 2012).

Fenomenologi pada penelitian ini bertindak sebagai metodologi. Moustakas menyebutkan bahwa fenomenologi merupakan strategi penelitian dimana di dalamnya peneliti mengidentifikasi hakikat pengalaman manusia tentang suatu fenomena tertentu. Memahami pengalaman-pengalaman hidup manusia, menjadikan filsafat fenomenologi sebagai suatu metode penelitian yang prosedur- 
prosedurnya mengharuskan peneliti untuk mengkaji subjek dengan terlibat langsung di dalamnya dengan durasi waktu yang realtif lama (Creswell, 2013).

Penelitian ini menggunakan teori interaksi simbolik George Herbert Mead. Teori ini menjelaskan bahwa interaksi simbolik merupkan suatu aktivitas yang merupakan ciri khas manusia, yakni berkomunikasi atau pertukaran simbol yang diberikan makna (Mulyana, 2010)

Ada tiga premis yang dibangun dalam interaksi simbolik. Pertama, individu merespons suatu situasi simbolik. Mereka merespons lingkungan, termasuk objek fisik (benda) dan objek sosial (perilaku manusia). Menurut teori ini, individu lebih berperilaku aktif dalam menentukan lingkungan mereka sendiri. Kedua, makna tersebut merupakan hasil dari proses interaksi dengan orang lain. Makna tidak melekat pada objek, melainkan dinegosiasikan pelalui penggunaan bahasa dalam sebuah interaksi sosial. Ketiga, makna berkembang dan disempurnakan saat interaksi berlangsung adanya perubahan interpretasi karena setiap individu melakukan proses berkomunikasi dengan dirinya sendiri (Mulyana, 2010)

Manusia bertindak terhadap orang lain berdasarkan makna yang diberikan orang lain pada mereka. Asumsi ini dikemukakan oleh West and Turner yaitu, makna diciptakan dalam interaksi antarmanusia, makna dimodifikasi melalui sebuah proses interpretif, individuindividu mengembangkan konsep diri melalui interaksi dengan orang lain, konsep diri memberikan sebuah motfi penting untuk berprilaku, orang dan kelomok dipengaruhi oleh proses budaya dan sosial, dan struktur sosial dihasilkan melalui interaksi sosial (West \& Turner, 2009).Kaitan penggunaan teori interaksi simbolik dengan penelitian ini adalah ketika seseorang memaknai sesuatu hal yang terjadi pada dirinya, maka sesuatu itu akan berpengaruh pada perilakunya untuk kemudian membentuk dirinya seperti apa.

Sebagai penelitian kualitatif yang mengedepankan kekayaan informasi terkait penelitian ini, peneliti memilih subjek penelitian yang memiliki integritas dan memiliki kompetensi untuk diteliti agar informasi yang dibutuhkan dapat diperoleh dengan baik. Subjek penelitian ini didapatkan dengan menggunakan purposive sampling. Peneliti telah menentukan siapa saja key informant untuk penelitian ini berdasarkan klasifikasi yang telah dibuat.

\section{HASIL DAN PEMBAHASAN}

Hasil penelitian ini diperoleh dari hasil wawancara dengan key informant yang telah ditentukan. Kriteria yang dibuat oleh peneliti antara lain, para key informant merupakan seorang YouTuber Kota Bandung, pria atau wanita, berusia lebih minimal 20 tahun, memiliki subscriber di atas 100.000, mahasiswa/pekerja/wiraswasta, dari berbagai genre, sudah berkarya minimal 3 tahun di YouTube. Berdasarkan kriteria tersebut, diperolehlah sebanyak 3 orang YouTuber yang menjadi key informant untuk dilakukannya wawancara mendalam. Dua diantara tiga YouTuber yang dipilih oleh peneliti merupapakan YouTube Ambassador Indonesia. Selain melakukan wawancara mendalam kepada para YouTuber ini, peneliti juga melakukan observasi partisipatif dengan mengikuti kegiatan para key informant. 
Kery Astina, YouTuber Parodi yang memiliki nama asli Kery Kartika lahir pada 9 Maret 1995 di Jakarta. Kery berhasil menjadi salah satu YouTuber yang menjadi peserta di program YouTube Next Up 2017. Perkembangan channel dari Kery Astina ini sangat signifikan. Pada awal 2017 jumlah subscriber-nya masih sebanyak 2000-an, hingga di penghujung 2017 sudah menyentuh angka 286.678 subscriber. Sehingga pada tahun 2017 ia sudah mendapatkan Silver Play Button. Di tahun 2019 ini, Kery Astina berhasil memperoleh subscriber sebanyak 2,1 Juta (YouTube, 2019).

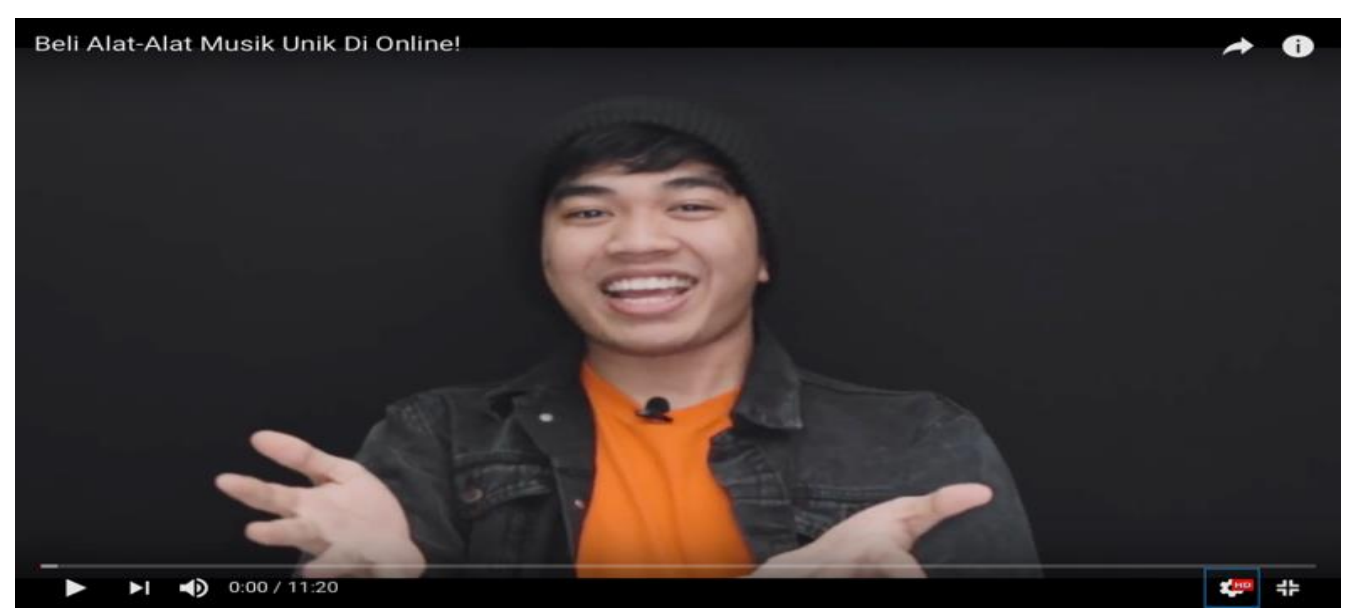

Sumber : (YouTube, 2019)

Gambar 1. Foto Kery Astina

Minyo merupakan seorang YouTuber yang bergenre beauty. Nama aslinya Vanya Qinthara yang lahir di Bandung pada 16 Februari 1992. Sebagai YouTube Ambassador Indonesia. Minyo juga merupakan seorang founder dari
Indonesian Beauty Vlogger (IBV) pada tahun 2015. Minyo juga merupakan lulusan dari PSB Academy Singapore The University of Newcastle Australia. Konten channel-nya banyak seputar tutorial makeup.

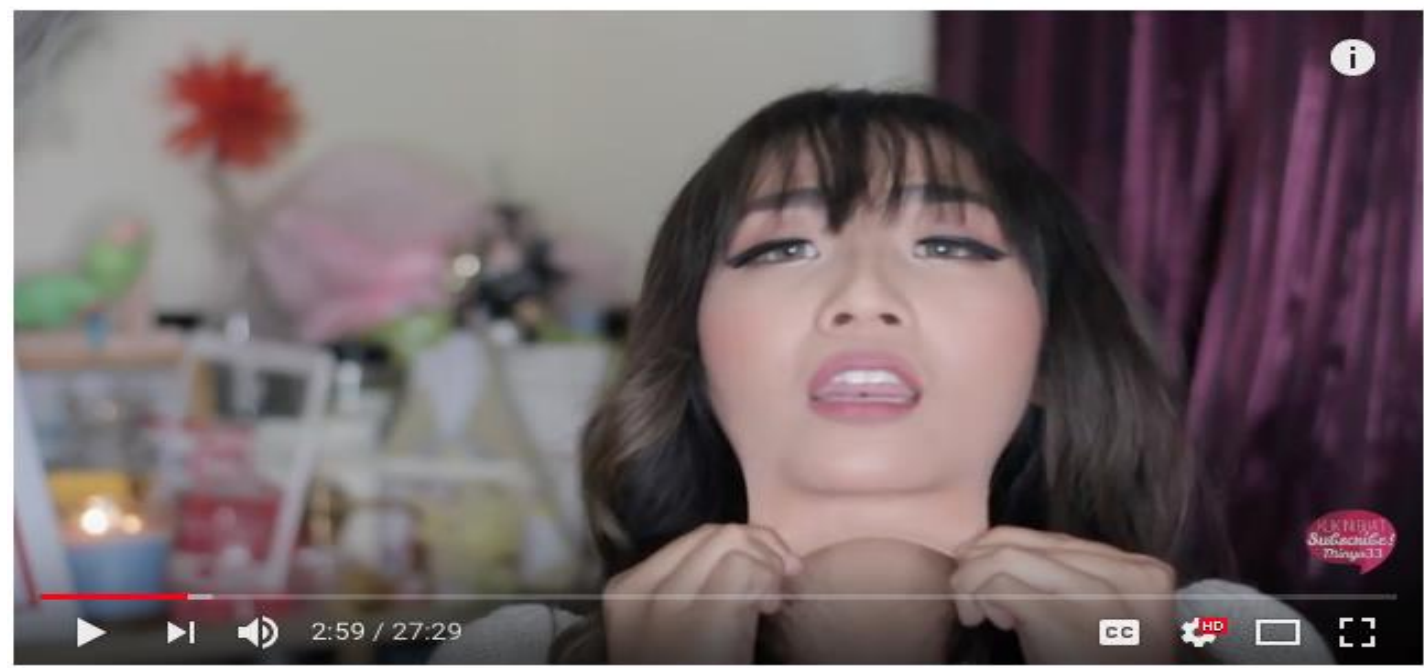

Sumber : (YouTube, 2019)

Gambar 2. Foto Minyo 
YouTube Ambassador lain yang menjadi key informant penelitian ini merupakan sosok yang selalu menyuarakan seorang YouTuber itu harus cerdas membuat konten. Ia adalah Eno Bening. Lahir di Jakarta 16 Agustus 1992 dan sempat tinggal di Bandung selama 2 tahun setelah lulus kuliah. Eno Bening memiliki konten YouTube kebebasan berpendapat terkait beberapa hal yang sedang trending di YouTube.

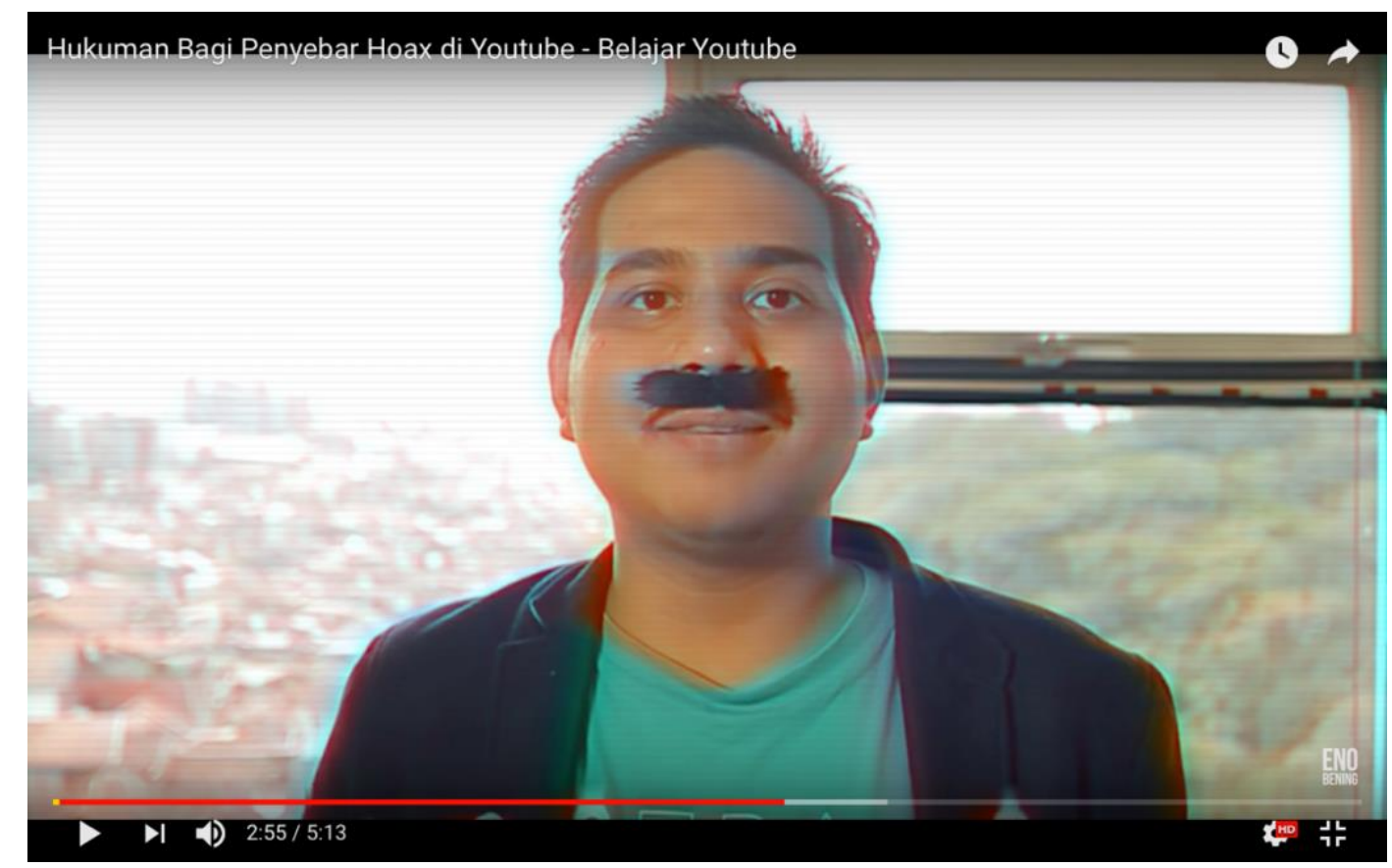

Sumber : (YouTube, 2019)

\section{Gambar 3. Foto Eno Bening}

1. Tabel Deskripsi Key Informant

\begin{tabular}{ccccccc}
\hline $\begin{array}{c}\text { Nama Key } \\
\text { Informant }\end{array}$ & $\begin{array}{c}\text { Nama } \\
\text { Channel }\end{array}$ & $\begin{array}{c}\text { Jenis } \\
\text { Kelamin }\end{array}$ & Usia & Pekerjaan & $\begin{array}{c}\text { Lama } \\
\text { Berkarya } \\
\text { di } \\
\text { YouTube }\end{array}$ & $\begin{array}{c}\text { Jumlah } \\
\text { Subscriber }\end{array}$ \\
\hline Kery Astina & $\begin{array}{c}\text { Kery } \\
\text { Astina }\end{array}$ & Pria & $\begin{array}{c}24 \\
\text { Tahun }\end{array}$ & $\begin{array}{c}\text { Wiraswasta } \\
\text { dan } \\
\text { YouTuber }\end{array}$ & 3 Tahun & 2,1 Juta \\
\hline Minyo & Minyo33 & Wanita & $\begin{array}{c}27 \\
\text { Tahun }\end{array}$ & YouTuber & 5 Tahun & 133 Ribu \\
\hline $\begin{array}{c}\text { Eno Bening } \\
\text { Swara }\end{array}$ & Eno Bening & Pria & $\begin{array}{c}27 \\
\text { Tahun }\end{array}$ & $\begin{array}{c}\text { Karyawan } \\
\text { Swasta dan } \\
\text { YouTuber }\end{array}$ & 10 Tahun & 419 Ribu \\
& & & & &
\end{tabular}

Sumber : (Astina, 2019)(Bening, 2019)(Minyo, 2019)dan data dari masing-masing YouTube Channel 
Membuat suatu video online adalah salah satu bentuk penyaluran ide kreatif yang tentunya dimiliki oleh seorang video maker, termasuk YouTuber. Seorang YouTuber akan menganggap dirinya sudah mendapatkan apresiasi jika ada orang yang menonton video yang dibuatnya dan juga menjadi pelanggan atau subscriberYouTube channel dari seorang YouTuber tersebut.

Kualitas konten video yang dibuat pun tentunya harus baik guna memperoleh subscriber yang banyak.Namun, banyak yang salah kaprah terkait hal ini, terutama YouTuber yang baru terjun ke dalamnya. Mereka kebanyakan rajin mengunggah video tanpa melihat kualitas dari video tersebut, terutama aspek editing, pengambilan gambar dan lain-lain. Dalam membuat konten video yang bagus, tidak ada yang instan, semuanya berproses. Sama halnya dengan mendapatkan subscriber yang banyak. Mereka akan datang dengan sendirinya jika konten yang dihasilkan oleh seorang YouTuber tersebut bagus dan menarik.

Jumlah subscriber pun menjadi tolok ukur kesuksesan para YouTuber. Namun, tidak semua YouTuber memandang jumlah angka subscriber tersebut sebagai kesuksesannya, bukan berarti hal tersebut membuat peran subscriber tidak penting. Ketiga key informant penelitian ini memiliki pandangan tersendiri terkait dengan subscriber tersebut. Mereka sangat menghargai dan memaknai subscriber-nya dalam dunia YouTube. Ada yang memaknainya sebagai teman, ada yang memaknainya sebagai fans, dan lain sebagainya.

Eno Bening memaknai subscribernya sebagai teman. Ia tidak mau ada jenjang antara subscriber dengan dirinya. Eno pernah mengalami star syndrome, ia menganggap bahwa subscriber adalah fans. Namun, setelah sekian lama dirinya berpikir lebih dewasa bahwa hal tersebut keliru. Hal tersebut menjadikan adanya jarak atau jenjang yang terjadi di antara dirinya dengan subscriber-nya. Eno pun tak sungkan mengatakan bahwa peran subscriber sangat bermakna bagi indikator rate card-nya untuk diberikan kepada calon pengiklan dan juga EO yang ingin menggunakan jasanya untuk memuat iklan ataupun menjadi pembicara di suatu acara terkait media sosial ataupun media digital, dan lain sebagainya.

Eno juga menilai subscriber juga adalah sosok yang loyal terhadap dirinya. Loyal dalam artian selalu menonton videonya, memberikan komentar (positif atau negatif), dan memberikan like atau disslike. Setelah mengangap subscribernya adalah teman, Eno selalu berupaya untuk menyempatkan diri mengajak subscriber-nya bertemu dan melakukan aktivitas bersama seperti makan malam, bahkan ia sempat membuat video bersama subscriber-nya.

"Gua ke Makassar kemarin itu gua ajak ngobrol subscriber gua, gua butuh feedback. Pengen tahu gua. Ketika gua bawa diskusi ke instagram, da nada yang respon bang konten ini sensitive segala macem ya akhirnya gua secara langsung diingetin gitu okay. Itu penting buat gua. Kayak kepuasan batin gua. Kalo ga ada feedback gua kayak orang yang gila sendiri aja gitu." (Bening, 2019)

Pertemuannya dengan subscriber dinilai akan lebih bermakna jika bertemu seperti itu daripada membuat event Meet and Great seperti YouTuber lain. Dengan 
cara yang mudah, Eno lebih bisa menghargai subscriber-nya.Meet and Great sendiri terkesan bahwa event tersebut semata-mata untuk mencari tambahan pundi-pundi uang secara "cumacuma" dengan memanfaatkan loyalitas dari subscriber. Hal tersebut dipandang Eno sangat memberatkan para subscribernya.

"Ga Meet and Great sih, Cuma ketemu ngobrol sekitar 2 atau 3 orang tau bahkan lebih dari itu. Yang penting ngobrol gitu cerita banyak hal, keliling main futsal atau bikin konten video bareng juga pernah. Gamau Meet and Great karena kesannya gue cari duit dari ketemu temen gue." (Bening, 2019)

Eno memberikan nama tersendiri untuk para subscriber-nya guna membedakan penonton setianya dengan penonton channel lain. Nama yang diberikan tergolong unik. Singham adalah nama yang diberikan Eno Bening kepada para subscribernya. Singham sendiri berasal dari bahasa India.

Nama tersebut diberikan bukan tanpa alasan. Ia meneritakan bahwa Singham adalah sebuah judul film India yang pernah ia tonton yang bercerita tentang seorang polisi yang jujur, penuh aksi menegangkan dengan efek visual yang menarik pada masanya. Singham sendiri adalah tokoh utama yang ada di dalam film tersebut.Singham sebagai polisi yang jujur yang tumbuh dan besar di lingkungan yang tidak baik, ia kemudian meyuarakan untuk tidak berbuat korupsi dan hal negatif lainnya yang merugikan masyarakat.

Pemilihan nama Singham sendiri berjalan lurus dengan tujuan Eno dalam membuat video di YouTube. Ia ingin menyampaikan keresahan dan berbicara lantang mengenai sesuatu hal yang masih dianggap tabu di masyarakat. Bahkan menariknya lagi, setiap konten yang ia buat berasal dari obrolannya dengan Singham.

"Iya gue panggil mereka Singham. Itu bahasa India artinya singa. Singa kan pemberani gitu kan. Itu sebenernya film polisi gitu sih. Salah satu film yang pernah gua tonton 12 kali. Favorit banget. Nah si Singham ini polisi yang bener gitu dan mau speak up tentang kejelekan-kejelekan yang ada gitu loh. Makanya gua akhirnya bikin channel yang speak up juga tentang sesuatu hal yang mungkin orang jarang bahas." (Bening, 2019)

Minyo menyampaikan hal yang hampir serupa. Subscriber adalah sosok yang sangat penting baginya dalam berkarya di YouTube. Sebagai seroang kreator, tentu pernah merasakan rasa jenuh dalam berkarya. Pada fase inilah, Minyo selalu meminta dukungan kepada subscriber-nya agar dirinya terus konsisten berkarya di YouTube. Feedback menjadi sebuah harapan dan juga sebuah bentuk dukungan bagi para YouTuber, termasuk Minyo.

Subscriber sendiri dimaknai olehnya sebagai seorang supporter yang selalu mendukung dirinya dalam berkarya dan membantu menemukan ide-ide baru untuk konten yang ia akan buat. Sama halnya dengan Eno, Minyo senantiasa menyukai pertemuan informal dengan subscriber-nya daripada pertemuan yang disengaja seperti Meet and Great berbayar. Ia beranggapan bahwa bertemu dengan subscriber waktunya harus bebas tidak terbatas sehingga kedekatan dirinya dengan subscriber bisa berjalan dengan 
baik dan mampu mendapatkan feedback secara langsung.

"Gue lebih seneng orang dateng ke gue bukan cuma buat minta foto aja, gue sangat menghargai kalo mereka ngasih tau, atau engga ngobrolin tentang konten gue. Kayak misalkan, kak Minyo aku suka banget nontonin story timenya kak minyo. Atau kak aku suka banget nontonin make up tutorialnya. Terus mereka ngasih tunjuk hasil tutorialnya kayak nih aku pake eyelash. Itu lebih berharga buat gue daripada sekedar minta foto atau kayak 1000 orang teriak-teriak gitu." (Minyo, 2019)

Minyo pun memiliki panggilan khusus untuk para subscriber-nya. Ia menamai subscriber-nya dengan sebutan Gumballs.Gumballs berarti permen karet yang berbentuk seperti bola dengan warna yang mencolok dan tahan lama apabila dikunyah. Minyo pun menjelaskan bahwa pemberina nama tersebut memang terinspirasi dari warna-warna dan tahan lamanya permen karet tersebut. Minyo berharap bahwa penontonnya itu bisa tahan lama dan loyal untuk menonton channel-nya. Warna-warni itu sendiri menggambarkan karakter setiap orang yang berbeda-beda. Memilih permen karet karena Minyo adalah manusia karet (memiliki kulit yang elastis dan tulang yang elastis).

"Filosofinya gini, itu kan permen karet ya gumballs itu yang buletbulet permen karetnya. Semua orang kayaknya suka permen karet. Terus gumballs itu warna-warni. Which is personallity nya orangorang yang nonton gue kan. Terus gumballs juga tahan lama rasanya. Ga langsung pecah si rasanya. Permen karet, i'm manusia karet gitu. Ya gue pengennya penonton gue tahan lama, walaupun ga begitu banyak tapi stay sama gue." (Minyo, 2019)

Subscriber itu adalah sosok yang penting juga bagi Kery Astina. Peran dari subscriber selama ini sangat penting untuk mendukung dirinya dalam berkarya di YouTube. Kery merasa jika tanpa adanya mereka, ia tidak bisa mencapai titik dimana ia memperoleh Gold Play Button. Dengan besarnya jumlah subscriber yang dimiliki, Kery pun mengungkapkan bahwa banyak pula pengiklan yang masuk ke dalam YouTube-nya dan pendapatan dari YouTube pun bertambah banyak.

Kery sangat money oriented. Hal ini disampaikan karena ia pun menganggap bahwa subscriber adalah harta baginya. Dengan bertambahnya mereka, maka penghasilan di YouTube pun bertambah banyak. Karena ia merasa bahwa subscribernya telah memberikan banyak uang kepada dirinya, feedback yang diberikan Kery kepada subscribernya adalah karya video yang bagus dan menghibur. Hal ini dilakukan agar para subscriber tidak kecewa.

Sama dengan kedua

YouTubersebelumnya, Kery lebih menyukai pertemuan informal dengan subscriber tanpa harus membuat event seperti Meet and Great berbayar. Kery tidak segan-segan untuk mengajak bertemu subscriber-nya ketika ia sedang berada di pusat perbelanjaan atau tempat lainnya.

"Wah penting banget kalo angka subscriber kita gede ya duit juga gede dapetnya kan, iklan banyak, views gede gitu. kita jualan ada yang beli. Kita bikin lagu ada yang denger gitu kan penting banget peran mereka buat gua. Udah kayak harta lah bagi gua mereka itu. Tapi karena gua anggap harta 
ya gua jaga, jaganya dengan cara gua bikin konten yang bagus." (Astina, 2019)

Namun, berbeda dengan Eno dan Minyo, Kery Astina tidak memberikan nama khusus untuk subscribernya.Hal tersebut dilakukan supaya tidak mengkotak-kotakan penontonnya.

Peneliti memperoleh jawaban yang beragam terkait dengan makna subscriber itu sendiri. Ada yang membuat nama khusus, ada pula yang tidak memberikan nama khusus. Ketiga key informant menyatakan pernah bertemu langsung dengan subscriber-nya. Berikut adalah tabel tipifikasi untuk mempermudah proses pembahasan serta pemahaman terkait makna subscriber ini. 


\section{Tabel Pemaknaan Subscriber Bagi YouTuber Kota Bandung}

\begin{tabular}{|c|c|c|c|}
\hline Nama & Makna Subscriber & $\begin{array}{l}\text { Nama Khusus } \\
\text { Subscriber }\end{array}$ & $\begin{array}{l}\text { Bertemu Dengan } \\
\text { Subscriber }\end{array}$ \\
\hline $\begin{array}{l}\text { Kery Astina } \\
\text { (Kery) }\end{array}$ & $\begin{array}{c}\text { Harta, karena dengan } \\
\text { banyaknya subscriber } \\
\text { pendapatan yang diperoleh } \\
\text { pun semakin banyak }\end{array}$ & 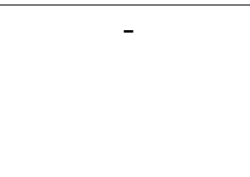 & $\begin{array}{l}\text { Pernah, mengajak } \\
\text { bertemu di mal, atau } \\
\text { tidak sengaja } \\
\text { ketemu. }\end{array}$ \\
\hline $\begin{array}{l}\text { Vanya Qinthara } \\
\text { (Minyo) }\end{array}$ & $\begin{array}{l}\text { Subscriber itu supporter yang } \\
\text { memberi semangat ketika } \\
\text { sedang buntu ide. } \\
\text { Orang yang selalu memberi } \\
\text { feedback terhadap kontennya }\end{array}$ & Gumballs & $\begin{array}{l}\text { Pernah, bertemu di } \\
\text { event MakeUp, } \\
\text { ngobrol, mendapat } \\
\text { banyak feedback } \\
\text { langsung. }\end{array}$ \\
\hline Eno Bening (Eno) & $\begin{array}{c}\text { Subscriber itu teman untuk } \\
\text { channel Eno Bening } \\
\text { Subscriber itu orang yang } \\
\text { loyal. } \\
\text { Subscriber itu orang yang } \\
\text { selalu memberikan feedback. } \\
\text { Subscriber itu indikator rate } \\
\text { card. }\end{array}$ & $\begin{array}{l}\text { Singham (Eno } \\
\text { Bening). } \\
\text { Spot Fam } \\
\text { (Clean Sound } \\
\text { Studio). }\end{array}$ & $\begin{array}{l}\text { Pernah, bertemu di } \\
\text { event YouTube, } \\
\text { bertemu di tempat } \\
\text { makan, sengaja } \\
\text { mengajak kumpul } \\
\text { bersama. } \\
\text { Mendengarkan } \\
\text { feedback subscriber. }\end{array}$ \\
\hline
\end{tabular}

Sumber : (Astina, 2019)(Bening, 2019)(Minyo, 2019)

Meninjau kembali teori interaksi simbolik yang dikemukakan oleh George Herbert Mead yang menekankan bahwa esensi dari interaksi simbolik adalah suatu aktivitas yang merupakan ciri khas manusia yakni berkomunikasi, atau melakukan pertukaran simbol yang diberikan makna. Kata-kata, suara, gerakan fisik, bahasa tubuh, pakaian dan status adalah contoh dari simbol yang bermakna. Dalam penelitian ini yang menjadi bahasan interaksi simbolik adalah subscriber.

Subscriber adalah orang yang berlangganan pada sebuah channel yang ada di YouTube. Setiap orang yang ingin berlangganan diwajibkan membuat akun YouTube terlebih dahulu. Bagi mereka yang sudah memiliki akun Google, tidak perlu membuat akun YouTube, tetapi langsung saja log in di YouTube. Setelah memiliki akun YouTube, pengguna dapat mengakses beberapa fitur seperti fitur komentar, like, share video, dan juga bahkan bisa membuat saluran sendiri.

Apabila seseorang tersebut sudah menjadi subscriber di salah satu channel tertentu, terdapat fitur tambahan seperti mendapatkan notifikasi melalui aplikasi YouTube ataupun Gmail bahwa channel yang telah di-subscribe telah mengunggah video baru. Dengan adanya notifikasi ini, subscriber dapat dengan mudah mengakses video baru dari YouTuber kesukaannya.

Peran dari subscriber ini dimaknai beragam oleh para YouTuber, termasuk key informant penelitian ini.Peran subscriber ini sangat penting bagi YouTube channel yang bersangkutan untuk mendapatkan berapa banyak iklan yang tayang di setiap video yang telah diunggah oleh para YouTuber. Setidaknya peneliti menemukan setidaknya 4 makna yang diberikan oleh YouTuber Kota Bandung terkait subscriber. 
Subscriber sebagai supporter, makna ini disampaikan oleh Minyo. Ia beranggapan dan menilai subscriber sebagai pendukung terhadap YouTube channel yang ia buat dan juga karya-karya yang telah atau yang akan dihasilkan. Dianggap sebagai supporter tentu sah-sah saja. Mengingat setiap YouTuber mempunyai kapasitas ide yang tidak selalu muncul di setiap saat untuk membuat konten di YouTube.

Subscriber sebagai indikator rate card. Makna ini disampaikan oleh Eno dan juga Kery Astina. Wajar apabila seorang YouTuber memandang hal ini karena berkat subscriber tersebutlah mereka mampu mendapatkan penghasilan dari media YouTube. Penghasilan yang diperoleh bisa dari iklan yang terpasang secara otomatis oleh sistem YouTube, maupun brand deals dimana pengiklan langsung menghubungi YouTuber tersebut untuk melakukan promosi dengan cara yang kreatif melalui video mereka di YouTube.

Subscriber sebagai teman. Hal ini dimaknai oleh Eno Bening. Ia membuat makna tersebut bukan tanpa alasan. Alasan pertama adalah ia tidak ingin ada jarak antara dirinya dengan subscriber. Ia tidak ingin seperti kebanyakan YouTuber yang menganggap bahwa subscriber adalah fans. Dengan beranggapan bahwa subscriber adalah teman, hal ini akan mempermudah dirinya jika sedang melakukan pertemuan dengan para subscriber sehingga tidak perlu ada rasa canggung atau seperti jumpa fans yang terkesan kaku dan terkesan matrealistis.

Subscriber sebagai pemberi feedback. Tidak hanya sekedar sebagai orang yang menonton video di YouTube, subscriber ini dimaknai oleh Minyo dan Eno yaitu sebagai orang yang selalu memberikan feedback. Feedback ini merujuk pada masukan, kritik dan saran pada kolom komentar yang terdapat di YouTube, suka atau tidak suka terhadap video yang sudah diunggah oleh para YouTuber. Minyo mengatakan bahwa feedback yang diharapkan adalah secara langsung bukan melalui komentar di YouTube. Ia selalu menginginkan pertemuan langsung dengan para subscriber-nya guna memperoleh kritikan dan masukan apapun tentang konten yang ia buat. Sedangkan Eno mengatakan feedback yang mereka sudah dapatkan dari subscriber-nya adalah para subscriber-nya sudah terpengaruh dengan baik dari konten yang dibuat oleh Eno. Ia berharap bahwa subscriber-nya mampu berpikir kritis terhadap segala persoalan sehari-hari yang dinilai risih di masyarakat.

3. Tabel Pemaknaan Para YouTuber Kota Bandung

\begin{tabular}{|c|}
\hline Pemaknaan Subscriber oleh YouTuber Kota Bandung \\
\hline Subscriber Sebagai Supporter \\
\hline Subscriber Sebagai Indokator Rate Card \\
\hline Subscriber Sebagai Teman \\
\hline Subscriber Sebagai Pemberi Feedback \\
\hline
\end{tabular}

Sumber : (Astina, 2019), (Bening, 2019), (Minyo, 2019) 


\section{SIMPULAN}

Pada hakikatnya semua manusia tentu akan memaknai sesuatu hal yang terjadi pada dirinya. Makna-makna tersebut hadir karena adanya interaski yang berlangsung dalam kehidupan sehariharinya, begitupun dengan para YouTuber ini. Mereka berkarya dengan media YouTube untuk mendapatkan banyak penonton dan juga subscriber. Kemudian, seiring berjalannya waktu merekapun memiliki pemaknaan tersendiri mengenai subscriber tersebut. Mereka memaknai subscriber berdasarkan hal dari adanya interaksi simbolik yang berlangsung melalui bertambahnya jumlah penonton serta melihat dari komentar dan juga penilaian suka atau tidak yang diberikan di dalam channel para YouTuber ini. Subscriber dimaknai oleh para YouTuber sebagai seorang supporter, sebagai indikator Rate Card, sebagai teman, dan juga sebagai orang yang selalu memberikan feedback.

\section{UCAPAN TERIMAKASIH}

Peneliti mengucapkan terimakasih kepada pihak yang telah banyak membantu dalam proses penelitian ini dari awal sampai selesainya tulisan artikel ini. Pihak-pihak tersebut yaitu rekan komunitas YouTube Creator Bandung, para key informan yaitu Kery Astina, Minyo dan Eno Bening, kepada Secilia selaku penghubung antara peneliti dengan YouTube Ambassador, kepada Bageru selaku Ketua Komunitas YouTube Creator Bandung yang sudah membuka akses kepada Kery Astina.

\section{DAFTAR PUSTAKA}

Academy, Y. C. (2018, August 28). Katalog. Retrieved from Dasar-Dasar YouTube: https://creatoracademy.youtube.com/p age/lesson/subscriber-

advantage?hl=id\#strategies-zippy-

link-2

Adi, A. N. (2017). Parental Control Untuk Anak Pengguna Media YouTube di Indonesia. Prosiding Seminar Nasional: Komunikasi dan Budaya di Tengah Pusaran Media dan Teknologi Informasi, 1-2.

Astina, K. (2019, August 4). Makna Subsriber. (A. N. Adi, Interviewer)

Bening, E. (2019, Agustus 3). Makna Subscriber. (A. N. Adi, Interviewer)

Brad, \& Debora. (2009). How to Make Money. Mc Graw Hill.

Creswell, J. (2013). Research Design Pendekatan Kualitatif, Kuantitatif dan Mixed. Yogyakarta: Pustaka Pelajar.

Crystal, J. (2011). The DisclosureIntimateLink in Computer-Mediated Communication: An Attributional Extension of Hypersonal Model. Human Communication Research ISSN 0360-3989.

Faiqah, F., Nadjib, M., \& Amir, A. S. (2016). YouTube Sebagai Sarana Komunikasi Bagi Komunitas Makassarvidgram. Jurnal Komunikasi KAREBA, 260261.

Fikrie, M. (2017, March 9). Durasi Tonton dan Jumlah Konten YouTube Indonesia Tumbuh Pesat. Retrieved from Kumparan Tech: https://kumparan.com/@kumparantech /google-durasi-tonton-dan-jumlahkonten-youtube-indonesia-tumbuhpesat

Goenawan, M. A. (2015, October 23). Durasi Nonton YouTube di Indonesia Tumbuh 130\%. Retrieved from detik.com: https://inet.detik.com/cyberlife/d3051966/durasi-nonton-youtube-diindonesia-tumbuh-130

Hajar, I. (2018). YouTube Sebagai Sarana Komunikasi Dakwah di Makassar. Jurnal Al-Khitabah Vol. 5 No. 2, 95. 
Labas, Y. N., \& Yasmine, D. I. (2017). Komodifikasi di Era Masyarakat Jejaring: Studi Kasus YouTube di Indonesia. Jurnal Pemikiran Sosiologi Vol. 4 No. 2, 105.

Minyo. (2019, August 3). Makna Subsriber. (A. N. Adi, Interviewer)

Moleong, L. (2012). Metodologi Penelitian Kualitatif Edisi Revisi. Bandung: Remaja Rosdakarya.

Mulyana, D. (2010). Metode Penelitian Kualitatif. Bandung: Remaja Rosdakarya.

Riyanto, A. D. (2019, February 9). Digital Marketing : Bisnis di Era Digital. Retrieved from andi.link: https://andi.link/hootsuite-we-aresocial-indonesian-digital-report-2019/

Searbrook, J. (2012, January 16). Magazine. Retrieved from Streaming Dreams The New Yorker: www.newyorker.com/magazine/2012/ 01/16/streaming-dreams

Social, W. A. (2019). Most Active Social Media Platforms in Indonesia. Hootsuite.
West, R., \& Turner, H. (2009). Pengantar Teori Komunikasi Edisi 3 Analisis dan Aplikasi. Jakarta: Salemba Humanika. YouTube. (2018, 3 29). YouTube Creators : Benefits and Awards. Retrieved from Celebrating Your Success: https://www.youtube.com/intl/enGB/creators/awards/

YouTube. (2019, 9 25). Kery Astina. Retrieved from https://www.youtube.com/user/kerryk artika/featured

YouTube. (2019, September 25). Eno Bening. Retrieved from https://www.youtube.com/channel/UC zK7WRnkii9PI3S2EMLUAZg

YouTube. (2019, September 25). Minyo33. Retrieved from https://www.youtube.com/user/vanyaj unsu 